Apidologie, 1983, 14 (3), 191-196.

\title{
EFFECT OF DIET $p$ H ON THE CONSUMPTION, BROOD REARING, AND $p$ H OF WORKER JELLY PRODUCED BY CAGED HONEY BEES
}

Elton W. HERBERT Jr., and H. SHIMANUKI

U.S. Department of Agriculture, ARS, PPI,

Bioenvironmental Bee Laboratory, Beltsville, MD 20705, USA

\begin{abstract}
SUMMARY
There were no significant differences in the $p \mathrm{H}$ of worker jelly produced by caged bees offered a pollen substitute ranging in $p \mathrm{H}$ from 4.1-8.0. Over $80 \%$ of all jelly sampled had a $p \mathrm{H}$ within the range 4.00-4.30. The greatest consumption was observed in bees of fered pollen and pollen substitutes with $p \mathrm{H}$ of $6.6,4.7$, and 5.5. The most brood was reared in units of bees fed diets with $p \mathrm{H}$ of 4.7 and 5.5. The study demonst rated that bees have the capability to buffer diets with extreme $p H$ 's and produce brood food within a narrow $p \mathrm{H}$ range.
\end{abstract}

\section{INTRODUCTION}

Most of the digestion of ingested food occurs in the ventriculus of the honey bee, where epithelial cells secrete the digestive enzymes. The products of digestion then go through the thin peritrophic membrane and are discharged through the ventricular wall directly into the surrounding hemolymph. Since digestive enzymes and the microbial flora are sensitive to changes in $p \mathrm{H}$, the gut $p \mathrm{H}$ of the honey bee must be maintained at a fairly constant level to insure maximum catalytic activity. The intestinal $p \mathrm{H}$ of the adult is 5.6-6.3 and that of the larva is 6.8 (Chauvin, 1962).

The glandular secretions fed to worker larvae (worker jelly) and queen larvae (royal jelly) are acidic. These secretions primarily from the mandibular and hypopharyngeal glands of young worker adults have a $p \mathrm{H}$ of 4.6-4.8 and 4.5-5.0, respectively (WIGGLESWORTH, 1961). Buffering systems within the bee maintain the gut and hemolymph $p \mathrm{H}$ at levels critical for survival because changes in $p \mathrm{H}$ could result in irreparable cell and tissue damage and possibly death. 
The present study was conducted : 1) to determine the $p \mathrm{H}$ of pollen collected during 1982 in Beltsville, MD; 2) to determine the optimum $p \mathrm{H}$ of a pollen substitute by measuring the rate of brood rearing and diet consumption by caged bees; and 3) to determine the influence of the $p \mathrm{H}$ of pollen and a pollen substitute on the $p \mathrm{H}$ of the resultant worker jelly produced by nurse bees.

\section{MATERIALS AND METHODS}

The $p \mathrm{H}$ of the pollen substitute (Herbert and ShImanuki, 1980) was adjusted to an acid or alkaline $p \mathrm{H}$ by adding a known volume of either $2 \mathrm{~N} \mathrm{NaOH}$ or $2 \mathrm{~N} \mathrm{HCl}$ and distilled water to $200 \mathrm{~g}$ of dry diet. The total volume of liquid $(50 \mathrm{ml})$ was maintained by adding $5 \mathrm{ml}$ and $10 \mathrm{ml}$ of either $\mathrm{NaOH}$ or $\mathrm{HCl}$ to 45 and $50 \mathrm{ml}$ of distilled water, respectively. The diet was then molded into a moist patty. The $p \mathrm{H}$ of the resultant diet was 4.1, 4.7, 5.5,6.6 and 8.0. Since the commercially formulated diet was $p \mathrm{H} 5.5$, no adjustment was necessary and only distilled water was added to the final diet. Fresh pollen collected weekly from free flying colonies of bees fitted with pollen traps was used as a control. The $p \mathrm{H}$ of the weekly pollen collection was determined by dispersing $10 \mathrm{~g}$ (wet weight) of fresh pollen in $40 \mathrm{ml}$ of distilled water.

The six diets were each offered to four nuclei $(23 \times 19 \times 27 \mathrm{~cm})$, each containing $400 \mathrm{~g}$ of newly emerged Italian bees (approximately 4,000 bees), a mated queen, and five drawn shallow combs $(3 \times 16 \times 24 \mathrm{~cm})$ free of pollen and honey. The nuclei were then placed in $2 \times 2 \times 2 \mathrm{~m}$ screen flight cages. Fifty grams of diet were offered weekly to each unit of bees by placing the diet in a petri dish lid that was inverted over the brood nest. The diet consumption was recorded weekly, and every second week the amount of sealed brood was measured using a wire grid $(2.54 \times 2.54 \mathrm{~cm}$ divisions $)$. These measurements continued from 4 June until 2 September 1982.

The $p \mathrm{H}$ of worker jelly was measured in individual worker cells containing 1 to 2 day old larvae using a MI-410 micro-combination $p \mathrm{H}$ probe (1) connected to an Orion 611 digital $p \mathrm{H}$ meter. The probe $(14 \mathrm{~cm}$ length and $1 \mathrm{~mm}$ lead length) can be used to measure the $p \mathrm{H}$ of jelly at a depth of $1.5 \mathrm{~mm}$. With smaller amounts of jelly, it was necessary to tear down the cell wall and hold the probe at an angle so that the reference electrode made sufficient contact. Whenever possible four individual measurements were made on each frame. The measurements were made biweekly except that later in the study insufficient jelly caused us to make measurements whenever the amount of jelly was sufficient.

The data were analyzed using split-plot in time (repeated measures design), and treatment differences were grouped (by date) according to Duncan's multiple range test.

\section{RESULTS AND DISCUSSION}

There were no significant differences in the $p \mathrm{H}$ of the worker jelly produced regardless of the $p \mathrm{H}$ of the diet offered (Table 1). There was no treatment $x$ date interaction when worker jelly was the dependent variable, which indicated that bees offered the various diets resporded the same over different time periods. Although the $p \mathrm{H}$ of the diets ranged from 4.1-8.0,83\% of all jelly sampled had a $p \mathrm{H}$ within

(1) Microelectrodes, Inc., Londonderry, New Hampshire 03053. 
TABL. 1. - The $\mathrm{pH}$ of worker jelly produced (1) by caged honey bees offered pollen or a pollen substitute at various $p \mathrm{H}$ levels.

\begin{tabular}{c|c|c|c|c}
\hline \hline & \multicolumn{4}{|c}{ DATE } \\
\cline { 2 - 5 } Diet $p \mathrm{H}$ & $16 \mathrm{June}$ & $2 \mathrm{July}$ & $15 \mathrm{July}$ & 10 Aug. \\
\hline 4.1 & $4.13 \pm .02$ & $4.16 \pm .02$ & $4.21 \pm .14$ & $4.09 \pm .03$ \\
4.7 & $4.09 \pm .01$ & $4.22 \pm .03$ & $4.45 \pm .04$ & $3.94 \pm .12$ \\
5.5 & $4.06 \pm .03$ & $4.25 \pm .01$ & $4.04 \pm .03$ & $4.11 \pm .03$ \\
6.6 & $4.08 \pm .02$ & $4.22 \pm .02$ & $4.06 \pm .03$ & $4.00 \pm .03$ \\
8.0 & $4.07 \pm .02$ & $4.17 \pm .02$ & $4.08 \pm .02$ & $3.94 \pm .04$ \\
Pollen (2) & $4.18 \pm .32$ & $4.18 \pm .01$ & $4.37 \pm .21$ & $4.24 \pm .02$ \\
\hline
\end{tabular}

(1) Mean \pm S.E. of four replications, with four subsamples in each replication.

(2) The $p \mathrm{H}$ of the pollen diet was as follows : 16 June $(p \mathrm{H} \mathrm{4.80),2} \mathrm{July} \mathrm{(4.86),} 15$ July (4.45), and 10 Aug (4.02).

the range 4.00-4.30. The two greatest deviations from this range were both observed in pollen fed bees. The most acidic jelly $p \mathrm{H}$ was 3.64 (pollen with a $p \mathrm{H}$ of 4.80 collected on 16 June), and the least acidic jelly was 4.58 (pollen with a $p H$ of 4.45 collected on 15 July). There were highly significant differences in time (three different groupings) when the $p \mathrm{H}$ of the worker jelly was the dependent variable. The $p \mathrm{H}$ was highest in midsummer ( 2 July and $15 \mathrm{July}$ ), with two other significantly different groups on 16 June and 10 August.

TABL. 2. - Amount of diet consumed ( $g$ ) (1) by honey bees offered either pollen or a pollen substitute at $\mathrm{pH}$ 's ranging from 4.1 to 8.0 .

\begin{tabular}{c|l|l|l|l|l|l}
\hline \hline Date & Pollen & 4.1 & 4.7 & 5.5 & 6.6 & 8.0 \\
\hline 22 June & $48.6 \mathrm{a}$ & $43.2 \mathrm{ab}$ & $44.9 \mathrm{a}$ & $47.2 \mathrm{a}$ & $40.5 \mathrm{ab}$ & $33.8 \mathrm{~b}$ \\
8 July & $54.0 \mathrm{a}$ & $41.5 \mathrm{~b}$ & $47.1 \mathrm{ab}$ & $45.8 \mathrm{ab}$ & $46.8 \mathrm{ab}$ & $39.4 \mathrm{~b}$ \\
$22 \mathrm{July}$ & $43.0 \mathrm{ab}$ & $35.3 \mathrm{bc}$ & $44.8 \mathrm{ab}$ & $44.9 \mathrm{ab}$ & $47.2 \mathrm{a}$ & $31.8 \mathrm{c}$ \\
5 Aug. & $40.1 \mathrm{a}$ & $37.6 \mathrm{a}$ & $43.1 \mathrm{a}$ & $40.4 \mathrm{a}$ & $48.2 \mathrm{a}$ & $26.0 \mathrm{~b}$ \\
19 Aug. & $37.6 \mathrm{a}$ & $15.8 \mathrm{c}$ & $33.5 \mathrm{ab}$ & $25.8 \mathrm{bc}$ & $32.4 \mathrm{ab}$ & $20.0 \mathrm{c}$ \\
2 Sept. & $29.6 \mathrm{a}$ & $4.5 \mathrm{~b}$ & $14.6 \mathrm{~b}$ & $7.9 \mathrm{~b}$ & $13.9 \mathrm{~b}$ & $9.0 \mathrm{~b}$ \\
\hline \hline
\end{tabular}

(1) Mean of four replications. Means in the same row followed by the same letter do not differ significantly at the $5 \%$ level of probability as calculated by Duncan's multiple range test.

There were highly significant differences in treatment, date, and treatment $x$ date interaction when diet consumption was the dependent variable. The consumption levels were essentially the same in bees offered pollen and pollen substitutes of $p \mathrm{H}$ of $6.6,4.7$, and 5.5 (Table 2). The diets with a $p \mathrm{H}$ of 4.1 or 8.0 were consumed less. Consumption by dates indicated that the diets fell into five significantly different groups, with most diet consumed on 8 July followed in decreasing order on the following dates : 22 June, 22 July, 5 August, 19 August and 
2 September. Consumption of the diets was best early in the study and decreased over the period of the test.

There were highly significant differences in treatment, date, and treatment $x$ date interaction with sealed brood the dependent variable. Statistically, bees

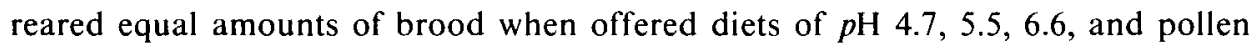
(Table 3). However, the most brood (mean of four nuclei) was reared in units fed diets with $p \mathrm{H}$ of $4.7\left(575.6 \mathrm{~cm}^{2}\right)$ and $5.5\left(549.1 \mathrm{~cm}^{2}\right)$ followed by $p \mathrm{H} 6.6\left(521.1 \mathrm{~cm}^{2}\right)$, $p \mathrm{H} 4.1\left(450.3 \mathrm{~cm}^{2}\right)$, and pollen $\left(426.5 \mathrm{~cm}^{2}\right)$. The smallest amount of brood was reared by bees offered the diet with a $p \mathrm{H}$ of $8.0\left(280.9 \mathrm{~cm}^{2}\right)$.

TABL. 3. - Amount of sealed brood $\left(\mathrm{cm}^{2}\right)(1)$ reared by honey bees offered either pollen or a pollen substitute at $\mathrm{pH}$ 's ranging from 4.1 to 8.0 .

\begin{tabular}{c|c|c|c|c|c|c}
\hline \hline Date & Pollen & 4.1 & 4.7 & 5.5 & 6.6 & 8.0 \\
\hline 22 June & $8.9 \mathrm{bc}$ & $95.0 \mathrm{a}$ & $26.2 \mathrm{ab}$ & $76.8 \mathrm{a}$ & $7.6 \mathrm{bc}$ & $2.5 \mathrm{c}$ \\
8 July & $31.5 \mathrm{a}$ & $81.9 \mathrm{a}$ & $126.1 \mathrm{a}$ & $106.5 \mathrm{a}$ & $108.6 \mathrm{a}$ & $89.6 \mathrm{a}$ \\
22 July & $139.2 \mathrm{a}$ & $128.6 \mathrm{a}$ & $145.0 \mathrm{a}$ & $155.6 \mathrm{a}$ & $154.6 \mathrm{a}$ & $99.3 \mathrm{a}$ \\
5 Aug. & $82.4 \mathrm{a}$ & $107.0 \mathrm{a}$ & $154.6 \mathrm{a}$ & $128.4 \mathrm{a}$ & $142.8 \mathrm{a}$ & $53.8 \mathrm{a}$ \\
19 Aug. & $94.3 \mathrm{a}$ & $26.2 \mathrm{a}$ & $105.4 \mathrm{a}$ & $69.8 \mathrm{a}$ & $82.8 \mathrm{a}$ & $24.4 \mathrm{a}$ \\
2 Sept. & $70.2 \mathrm{a}$ & $11.6 \mathrm{~b}$ & $18.3 \mathrm{ab}$ & $12.0 \mathrm{~b}$ & $24.7 \mathrm{ab}$ & $11.3 \mathrm{~b}$ \\
\hline
\end{tabular}

(1) Geometric Mean = Antilog $(\log Y$ ). Means (of four replications) in the same row followed by the same letter do not differ significantly at the $5 \%$ level of probability as calculated by Duncan's multiple range test.

The amount of brood rearing depended on date with six different groups as follows, starting from the greatest amount to the smallest amount of brood : 22 July, 5 August, 8 July, 19 August, 22 June, and 2 September.

The pollen collected weekly ( 19 March-12 October) from pollen traps placed on free flying colonies showed a range in $p \mathrm{H}$ from 5.83 (7 May) to 3.99 (17 June). The monthly averages showed that the pollens with the lowest $p \mathrm{H}$ were collected in June and those with the highest $\mathrm{pH}$ in April. Although none of the pollen samples had a $p \mathrm{H}$ over 5.83 , the fact that bees fed a pollen substitute with a $p \mathrm{H}$ of 8.0 could consume $160 \mathrm{~g}$ of this diet and rear $280.9 \mathrm{~cm}^{2}$ of brood to the sealed stage indicates that bees can buffer diets whith such an extreme $p \mathrm{H}$.

A preformulated commercial preparation of the Beltsville Bee Diet had a $p \mathrm{H}$ of 5.5. In the present study we found no evidence to merit changing the $p \mathrm{H}$ of this diet, on which brood rearing and consumption were fully adequate.

We also found that the $p \mathrm{H}$ of worker jelly deviates very little from 4.0 to 4.3. Although we found that bees will eat diets with much higher $p \mathrm{H}$ 's, this finding may not be pertinent in nature, since the $p \mathrm{H}$ of most pollens collected by bees appears to range between 3.64 and 4.58 . 
RÉSUMÉ

\section{INFLUENCE DU $p$ H DE LA NOURRITURE SUR LA CONSOMMATION, L'ÉLEVAGE DU COUVAIN} ET LE $p$ H DE LA GELÉE D'OUVRIĖRES PRODUITE PAR DES ABEILLES ENCAGÉES

Le $p \mathrm{H}$ d'un succédané de pollen a été fixé à 4,$1 ; 4,7 ; 5,5 ; 6,6$ et 8,0 à l'aide de $\mathrm{NaOH}$ ou $\mathrm{HC} 1$ à $2 \mathrm{~N}$. On a donné ce produit à 4 nucléi d’abeilles italiennes récemment écloses, noté chaque semaine la consommation alimentaire et mesuré tous les 15 jours la quantité de couvain operculé. A titre de témoin, on a utilisé du pollen frais prélevé chaque semaine dans des colonies en plein air. Le $p \mathrm{H}$ de la gelée d'ouvrières a été mesuré dans des cellules d'ouvrières renfermant des larves d'un ou deux jours.

On n'a pas trouvé de différence significative dans le $p \mathrm{H}$ de la gelée d'ouvrière en fonction du $p \mathrm{H}$ de la nourriture offerte. Les $p \mathrm{H}$ de la nourriture s'étendaient de 4,1 à 8,0 ; néanmoins $83 \%$ des échantillons de gelée avaient un $p \mathrm{H}$ compris entre 4,00 et 4,30. La consommation la plus élevée a été observée chez les abeilles auxquelles on avait donné du pollen et des succédanés ayant un $p \mathrm{H}$ de $6,6,4,7$ et 5,5 . Les abeilles nourries avec un régime à $p \mathrm{H} \mathrm{4,7} \mathrm{et} \mathrm{5,5} \mathrm{ont} \mathrm{élevé} \mathrm{le} \mathrm{plus} \mathrm{de} \mathrm{couvain,} \mathrm{suivies} \mathrm{par} \mathrm{celles} \mathrm{ayant} \mathrm{reçu}$ une nourriture à $p \mathrm{H} 6,6$ et 4,1 puis celles nourries au pollen. La plus petite quantité de couvain a été trouvée chez les abeilles dont la nourriture avait un $p \mathrm{H}$ de 8,0 .

Le $p \mathrm{H}$ du pollen prélevé chaque semaine (du 19 mars au 12 octobre) dans des trappes à pollen placées sur des colonies à l'air libre a varié entre 5,83 (7 mai) et 3,99 (17 juin). Le $p \mathrm{H}$ d'aucun des échantillons de pollen n'a été supérieur à 5,83 , mais le fait que les abeilles nourries avec un succédané à $p H$ H 8,0 aient pu en crnsommer $160 \mathrm{~g}$ et élever $280,9 \mathrm{~cm}^{2}$ de couvain jusqu'au stade operculé, indique que les abeilles sont capables de tamponner les nourritures qui présentent un tel $p \mathrm{H}$ extrême.

\section{ZUSAMMENFASSUNG}

EINFLUSS DES $p$ H-WERTS DER NAHRUNG AUF DEN VERZEHR, DIE BRUTAUFZUCHTRATE UND DEN $p \mathrm{H}$-WERT DES LARVENFUTTERS BEI GEKÄFIGTEN HONIGBIENEN.

Der $p \mathrm{H}-$ Wert eines Pollen-Ersatzmittels wurden mit Hilfe von $2 \mathrm{~N} \mathrm{NaOH}$ oder $\mathrm{HCl}$ auf 4.1, 4.7, 5.5, 6.6 oder 8.0 eingestellt. Je vier Kernvölkchen mit frisch geschlüpften Italiener-Bienen wurden mit diesen Pollen-Ersatzmitteln gefüttert. Der Nahrungsverbrauch wurde wöchentlich und die Menge an verdeckelter Brut alle zwei Wochen registriert. Als Kontrolle wurde frischer Pollen, der wöchentlich von frei fliegenden Kolonien gesammelt wurde, verfüttert. Der $p H-W e r t$ des Larvenfutters wurde in einzelnen Arbeiterinnenzellen mit 1-2 Tage alten Larven gemessen.

Es wurden keine signifikaten Unterschiede im $p H-W e r t$ des Larvenfutters festgesiellt trotz der großen Unterschiede im $p \mathrm{H}$-Wert des angebotenen Futters. Obwohl der $p \mathrm{H}-$ Wert der Nahrung von 4.1 bis 8.0 reichte, hatten $83 \%$ der untersuchten Larvenfutterproben einen $p$ H-Wert zwischen 4.0 und 4.3.

Der Nahrungsverbrauch war am größten bei den Bienen, die mit Pollen oder Pollenersatzmitteln mit dem $p H$-Wert von $6.6,4.7$ oder 5.5 gefüttert wurden.

Die größte Brutaufzuchtrate wurde in den Völkchen gefunden, deren Nahrung einen $p \mathrm{H}-$ Wert von 4.7, 5.5, 6.6 oder 4.1 aufwies, gefolgt von den mit frischem Pollen gefütterten Völkchen. Die geringste Brutaufzuchtrate fand man bei den Bienen, die mit einer Nahrung vom $p H 8.0$ gefüttert wurden. Der frische Pollen wurde wöchentlich (19. März bis 12. Oktober) in Pollenfallen an frei fliegenden Völkern gesammelt und wies einen $p \mathrm{H}-$ Wert von 5.83 (7. Mai) bis 3.99 (17. Juni) auf. Obwohl der $p H$-Wert des frischen Pollens 5.83 nicht überstieg, verzehrten die Bienen, denen Pollen-Ersatzmittel vom $p \mathrm{H}-$ Wert 8.0 geboten wurde, $160 \mathrm{~g}$ des Futters und zogen $280.9 \mathrm{~cm}^{2}$ Brut bis zum verdeckelten Stadium auf. Dies weist darauf hin, daß die Bienen den $p \mathrm{H}$-Wert der Nahrung puffern können. 


\section{REFERENCES}

Chauvin R., 1962. - Nutrition de l'abeille (Bee nutrition). Ann. Nutr. Aliment. 16, 4|-63.

Herbert E. W. Jr., and H. Shimanuki, 1980. - An Evaluation of Seven Potential Pollen Substitutes for Honey Bees. Amer. Bee J. 120 (5), 349-350.

WigglesworTh V. B., 1961. - The Principles of Insect Physiology. E. P. Dutton and Co., NY Editors, $546 \mathrm{p}$. 